\title{
Social Security Membership and Saving: The Turkish Case
}

Çă̆açan DEĞER (https://orcid.org/0000-0001-8555-4632), Department of Economics, Ege University, Turkey; e-mail: cagacan.deger@ege.edu.tr

Elif ERER (https://orcid.org/0000-0002-2238-4602), PhD in Economics, Independent Researcher, Turkey; email:elif_erer_@hotmail.com

\section{Sosyal Güvenlik Üyeliği ve Tasarruf: Türkiye Uygulaması}

\begin{abstract}
This study analyses the micro-foundations of the saving behaviour in Turkey, looking for a humpback profile in saving rates. Household Expenditure Surveys are used to construct a pseudo-panel of the saving rate. Then, an age-cohort-period decomposition is undertaken to isolate the agedependent behaviour of the saving rate in Turkey. The analysis is repeated for sub-samples based on social security status. Further investigation is carried out with truncated regression. Existence of a humpback profile is confirmed, but no systematic link between social security membership and the humpback profile is identified.

Keywords $\quad$ : Saving Behaviour, Life Cycle Models of Saving, Panel Data Models.

JEL Classification Codes : D14, D15, C33.

\section{Öz}

$\mathrm{Bu}$ çalışma Türkiye'de tasarruf oranlarında kambur bir profil olup olmadığını inceleyerek tasarrufun mikro temellerini araştırmaktadır. Hanehalkı Bütçe Anketleri kullanılarak bir yapay panel veri seti oluşturulmuştur. Daha sonra yaş-kohort-zaman ayrıştırması ile Türkiye'de tasarruf oranının yaşa bağlı davranışı incelenmiştir. Analiz, sosyal güvenlik sistemi üyeliğine göre oluşturulan alt örneklemler için tekrarlanmıştır. Kesikli inceleme de yapılarak analiz derinleştirilmiştir. Kambur bir profilin varlığı teyid edilmiştir fakat kambur profilin varlığı ile sosyal güvenlik üyeliği arasında düzenli bir bağıntı gözlemlenmemiştir.
\end{abstract}

\section{Anahtar Sözcükler $\quad$ : Tasarruf Davranışı, Tasarrufun Yaşam Döngüsü Modelleri, Panel} Veri Modelleri. 


\section{Introduction}

Saving is considered to be one of the main macroeconomic indicators. National income identities reveal that saving has a crucial role in financing the current account deficit, budget deficit and investment. In growth models saving is one of the main determinants of growth due to its contributions to capital accumulation. Hence saving is a closely watched macroeconomic aggregate. It also has an important micro dimension as well. Since it can be considered as the main method to move resources through time or the main claim on future consumption, saving is one of the important variables in dynamic consumer behaviour.

The role of saving on a micro dimension has important social security related impacts as well. This importance is especially highlighted within the context of the rise of private retirement funds within the last couple decades. Having arisen due to the financial problems of the public pillars, this rise of individualised retirement focused saving mechanisms call for saving behaviour to be analysed.

Inadequacy of saving in Turkey is frequently emphasised in both academic and policy literature. A quick glance at the Social and Economic Indicators of the Ministry of Development shows that the current account deficit to GDP ratio in Turkey is 7\%, and the saving-investment difference is $6 \%$ for the 2010 to 2014 period. Even though government deficit is relatively low during this time period, it is obvious that savings are not sufficient to cover the existing deficits.

Having come about as part of the evolution of social security systems, private retirement systems may contribute to saving. But the system has still not matured in Turkey in terms of coverage and accumulated funds. While considering the importance of such saving mechanisms, differences between groups of individuals should be considered as well. The most obvious example of this in Turkey is the subgroups of individuals differentiated due to their social security membership.

As a reflection of the fragmented institutionalisation history of Turkey, different individuals have different social security coverages. These differences are related to work status of individuals. While a group is public employees (4c, Retirement Fund, ES), a group works under service contracts (4a, Social Insurance Institution, SSK) whereas a third group is compromised of artisans and independent workers (4b, Institution for Artisans and Independent Workers, BK). Yet an other group is informally employed.

The aim of this study is to examine the saving behaviour over the life cycle of these different groups of individuals. Existence of a humpback profile in saving rates over the life cycle is investigated. It is also questioned whether the profile is different for different social security coverages. Within this context, saving rates have been calculated by age and age impact on saving rates have been analysed.

Previous literature on saving in Turkey can be broadly classified into two groups: one with a macro focus and an other one with a micro focus. Macro studies analyse saving in 
relation to macroeconomic aggregates (Özcan \& Günay \& Ertaç, 2003; Düzgün, 2009; Matur \& Sabuncu \& Bahçeci, 2012; Tatlıyer, 2017). On the other hand, studies with a micro focus employ large datasets such as the Household Budget Surveys to understand which personal characteristics influence saving (Rijckeghem \& Üçer, 2009; Aktaş \& Güner \& Gürsel \& Uysal, 2012; Ceritoğlu, 2013; Ceritoğlu \& Eren, 2014).

This study belongs to the group of micro data focused studies. For the Turkish case, Household Budget Survey data for years 2015 and 2016 are used to calculate saving rates. Then the existence of a humpback profile in saving rates is investigated through firstly a pseudo panel (Deaton, 1985). Despite the existence of micro data that extends to previous years, the pseudo panel analysis is restricted to only two years. For the variable on social security coverage does not provide the details necessary for the analysis to be conducted for earlier years. Secondly, the data is taken at an individual level and a truncated regression is run to account for a number of control variables and account for the cleaning up done to the data.

The analysis has two main contributions. Firstly, one of the methods employed is the generation of a pseudo-panel; this is hardly ever done on Turkish data and thus contributes by employing an existing method on a set of data previously not used. Secondly, this is the only study in the literature that explicitly analyses impact of social security coverage on saving behaviour.

The methodological contribution is through the pseudo-panel method develop by Deaton (1985). Deaton (1985) puts forward that when a panel data set is not available, a pseudo-panel can be generated from a time series of cross section datasets. In this study, Household Budget Surveys (HBS) from Turkish Statistical Institute have been used to generate such a pseudo-panel. The method has been used previously by Cilasun (2009) and Değer (2011). Cilasun (2009) has generated the dataset from 2002-2005 HBS but has not examined saving behaviour in connection with social security. Değer (2011) has employed 2003-2005 data but has left informal employment out of the analysis. This paper improves by considering informality as well and using a much recent data.

The other contribution of this study is through accounting for diversity in terms of social security. A minor empirical finding on social security membership on saving is reported only by Rijckeghem and Üçer (2009: 73). They report that BK membership increases the saving rate. However, they do not cross their analysis with age to form an opinion on life cycle behaviour. This is one of the missing points in the literature that we address through this paper.

The article proceeds by presenting a brief theoretical review of saving. This is followed by the conducted analysis, with notes on adopted methods and datasets. First a pseudo-panel construction is undertaken. Then the data is further examined through a truncated regression implementation. Upon the presentation of results, we conclude with a brief discussion. 


\section{Literature Review}

Absolute income hypothesis is one of the most commonly referred theories of saving. Based on the ideas of Keynes (1936) absolute income hypothesis states consumption, therefore saving, as a ratio of disposable income. This view has been heavily criticised through the analysis of the long term data (Kuznets, 1942). One of the leading ideas in the subsequent search for alternative formulations is the relative income hypothesis (Duesenberry, 1949) which focused on the role of the relative position of the individual in the distribution of income, rather than an absolute measure of income.

An other theory put forward is the permanent income hypothesis (Friedman, 1957) which argues that income and consumption have permanent and temporary components. In accordance with the humpback profile of income throughout a person's life, saving will fluctuate to preserve a smooth consumption profile. Relating age and saving more explicitly are the inter-temporal decision making processes put forward by Fisher (1930) and Modigliani's studies from 1950s on the life cycle hypothesis. Such a perspective can be summarily explained through a simple OLG (overlapping generations) model in the tradition of Diamond (1965).

Aksoy (2016: 11-19) reviews the empirical research literature on the determinants of private saving and lists income, interest rate, inflation, terms of trade, money and credit flows, current account position, foreign savings, money supply, old dependency ratio, young dependency ratio, urbanisation, income distribution, public saving and types of retirement systems as having an impact on national private saving. He then proceeds to analyse the impact of credits on saving and points out that the availability of credits has a negative impact on saving.

However, the works presented by Aksoy (2016) are based on aggregate data and despite the insights they provide, they do not exactly match the focus of this study on micro foundations. Empirical studies of saving based on survey data, or micro data, cover a considerable time and geography despite data availability limitation, especially in developing economies. To emphasise the historical origins of such studies, Snyder (1974)'s work on a review of saving studies on developing economies can be given. Snyder (1974) identifies income, wealth and household demographics worthy of note in the review.

More recently, Burney and Khan (1992) analyse the case of Pakistan through income, household demographic structure, education, occupational structure and age. For New Zealand, saving rate is related to cohort, age, houehold head gender, ethnic origins, employment status, house ownership and family structure (single, parent, nuclear, etc) through Household Economic Surveys (Gibson \& Scobie, 2001). Harris, Loundes and Webster (2002) employ a consumer survey of more than 17 thousand households to analyse micro foundations of saving. They use 5-age groups from age 18 to 64 , income, measures of wealth such as home ownership, the number of children, the region of residence and the interest rate. Dependent variable is a categoric variable that reflects the self reported 
financial position of the household through phrases such as "running into debt" or "saving a lot".

For the case of Morocco, Abdelkhalek, Arestoff, de Freitas and Mage (2010) relate the saving level of households to income, literacy level, household size, gender of the household head and a number of agricultural wealth indicators such as livestock and land ownership. Using data from a survey they have conducted in the Multan district of Pakistan, Rehman, Faridi and Bashir (2010) use income, wealth (in the form of land and livestock holdings), age, education, region of residence, demographic characteristics and labour market participation of household members. Obayelu (2013) emphasises age, household size, education, farming experience and land and livestock ownership for an analysis of the Kwara state of Nigeria. Employing micro dataset from 10 different Latin America countries, spanning a time period from 1994 to 2012, Bebczuk, Gasparini, Amendolaggine and Garbero (2015) relate saving behaviour to income, education, house and car ownership, age, household head gender and demographics of the household. Baidoo, Boateng and Amposanh (2018) analyse the impact of financial literacy on saving decisions and include age, gender, education, marital status, wealth, income and household size in their analysis of Ghana.

Based on the review of empirical studies, this study focuses on income, wealth, financial literacy, education and age. The relationship between saving and income is well established, permanent, temporary or lifetime income based theories cited above being the prime examples. Wealth is also well established as a determinant of saving behaviour. Nagatani (1972) provides intuition in a simple life-cycle model framework as to how wealth is related to consumption and saving behaviours and highlights the importance of isolating wage income and wealth in modelling representative consumer behaviour. Buffer-stock approach to consumer behaviour, where consumer behaviour is affected by a target wealth level, is an other theoretical approach (Carroll, 1997).

Regarding the impact of education, Attanasio (1998: 598) states that education may be important in terms of saving for it contributes to agent heterogeneity and therefore different reactions to similar shocks. Such heterogeneity even leads Jappelli (1999) to split a cross-section of Italian households by educational attainment of the household head while investigating saving behaviour. More recently, it has been argued that education increases financial literacy and thus increases saving and the effect is especially stronger for those with economics-related education backgrounds (Toth \& Lancaric \& Savov, 2015).

In a leading paper, Campbell (2006) finds that some households may commit crucial errors in investment planning and that such actors tend to be less educated. This has led to a search for an understanding of the role of financial literacy in saving behaviour. Related literature keeps growing. Brounen, Koedijk and Pownall (2016) examine Dutch household data and conclude that saving rate falls with age but increases with financial literacy. For Zimbabwe, Murendo and Mutsonziwa (2016) report that financial literacy has a positive impact on saving. Using a multiperiod model and empirical investigation, Jappelli and Padula (2013) relate financial literacy and wealth accumulation. Lusardi and Mitchell (2014) 
review theoretical grounds and how financial literacy is cast into economic models as a form of human capital.

The impact of ageing has been theoretically established through the life-cycle models of consumer behaviour (Modigliani, 1966). The basic idea is that a consumer saves during times of high income and dis-saves during times of low income. Applied to a representative consumer who work for a number of years and then retires with a pension lower than wage income, this approach presents not only a humpback saving profile but also may reveal important insight into policy making (Auerbach \& Kotlikoff, 1987). This paper investigates the existence of such a humpback profile in saving behaviour for the case of Turkey.

Such examinations of micro founded behaviour have already been conducted for Turkey. Cilasun (2009) and Değer (2011) confirm the existence of such patterns. This paper adds on these studies through the following contributions: i) Although Değer (2011) accounts for diversity in terms of social security, the case of informally employed individuals is not accounted for. This paper contributes by adding the case of the informally employed. ii) The mentioned studies focus on the data prior to 2005. The current study employs more recent data, i.e. the data for years 2015 and 2016. iii) The pointed studies generate pseudo panels as proposed by Deaton (1985). This paper follows suit, but enhances the analysis by employing a truncated regression which is able to account the biases introduced by some data cleaning practices and is able to account for a number of variables that have theoretical basis with regards to consumer behaviour in economics. Building on the review presented above, the study proceeds by firstly constructing a pseudo-panel structure and then deepening the analysis through a truncated regression analysis.

\section{Analyses}

Two analyses are conducted. First, a pseudo-panel is generated to examine the lifecycle flow of the saving rate. At the second stage a microeconometric analysis is conducted by adopting a truncated regression approach.

The pseudo panel method is very commonly used to identify age effects. The method enables the formation of a panel data structure, to a certain extent, when there is none. Thus a time dimension can be added to consecutive cross section data sets. There are two important shortcomings to the method. Firstly, when the isolation of pure age effects is attempted, the linear dependence between age, time and cohort imposes restrictions on the mathematics of the estimation procedure. A common solution is to drop one of the three dimensions and focus on age effects. This approach is adopted in this study. Secondly, during the formation of a pseudo panel, representative observation for an age group is generated by using a measure of central tendency on the relevant age group. Thus the individual or household level observations are aggregated to a single observation, causing a considerable loss in data diversity. It becomes almost impossible to control for variables that are specific to a cross section unit in a pseudo panel, as that data is lost during the aggregation to an age group. 
In order to analyse the diversity implied at the cross section unit level, the pseudo panel analysis is supplemented by a truncated regression analysis, a method due Tobin (1958). Due to a number of extreme values observed in the data set, the data had to amputated by taking a range into consideration for the dependent variable. Failure to take into account this truncation of the data would yield biased and inconsistent parameter estimates (Heckman, 1979; Long, 1997: 188-192) and therefore the appropriate estimation strategy has been adopted. The following sections of the paper summarizes the adopted methods and the results from the implementation of these methods.

\subsection{Pseudo-Panel Analysis: Method}

The first method used here is the compilation of a pseudo-panel data based on Deaton (1985). Panel datasets that follow cross section units through time are mostly not available, especially in developing countries. Thus analysis of micro data is restricted to cross section analysis and loses the finesse implied by the variation of the time dimension of the data. This shortcoming can be accommodated to a certain degree through the construction of pseudopanel datasets.

The approach rests on the idea that measures of central tendency can represent a cohort of cross section units, grouped by a common characteristic. The variable of interest here is the saving rate. The rate has been calculated for 2015 and 2016 using Household Budget Survey data for all individuals. For each age group, means of calculated saving rates have been taken. The basic assumption is that the average saving rate for an age group at a certain year is representative of the saving rate for a theoretical representative consumer of that age. Since this is applied to two years, a panel data set with two years as the time dimension can be artificially constructed. The cross section units are identified by age. To clarify, consider a representative theoretical individual aged 30 in year 2015. The saving rate of this theoretical individual is the average of the saving rates of all individuals aged 30 in the 2015 dataset. In year 2016, the theoretical representative individual becomes 31 . Now, the saving rate is the average saving rate of all the individuals aged 31 in the 2016 dataset. Thus, for each age available in the dataset, a two year panel is formed. Following this approach, a two year panel based on 2015 and 2016 is generated.

One problem is that the expenditure, income and age data are embedded in different subsets of the HBS dataset. Income is in the dataset for households, whereas age and individual income is immersed in the individuals dataset. These two subsets of data have to be merged, taking into account the OECD equivalence scales for transforming household expenditures to individual expenditures. The merger is enabled through the identification codes in both datasets. Saving rate is calculated as the difference between the individual's income and consumption expenditures.

Due to the lack of detailed data for the previous years, the study focuses on 2015 and 2016. In the 2011 to 2014 datasets, the question related to social security coverage is different and does not entail different social security coverages as answer options. Hence social security institution membership detail is lost, rendering the data useless for this study. 
The 2010 database reports age groups, rather than single ages. In order to evade the distortionary effects of the 2008 crisis, the data from previous years have been omitted. For the 2015 and 2016 years, the calculated average saving rates and standard deviations for each age group are reported in Appendix Tables 1 and 2.

Isolation of the age effects from a pseudo panel relies on age-period-cohort decomposition. But, since cohort is based on the year of birth and is directly related to age and time period, there is a linear connection between these variables. Consider an individual born in 1980, aged 36 in 2016. Since $2016=1980+36$, the connection is evident. This linear dependency is avoided by dropping cohorts. Thus the econometric estimation conducted on the pseudo-panel is based on the following estimation equation:

$$
s_{y t}=\alpha_{y t}+\beta_{1} a_{y t}+\beta_{2} a_{y t}^{2}+\beta_{3} a_{y t}^{3}+\beta_{4} P E R I O D+\varepsilon_{y t}
$$

Here $s_{y t}$ is the saving rate at time $t$ age $y$. Age is denoted $a_{y t}$. Age effects are accounted for by a third degree polynomial to take into consideration the tail effects. This also introduces the possibility to check whether the saving rate falls or remains flat at later ages. The PERIOD variable is a dummy variable that accounts for time effects, taking the value of 1 for year 2016 and 0 otherwise.

\subsection{Pseudo-Panel Analysis: Results}

The unprocessed data obtained from the construction of the pseudo-panel is visually presented in Figure 1. The figure reveals two main points. Firstly, saving rates do not differ much among groups with different social security coverage. This is especially interesting for the individuals informally employed. Informally employed individuals are generally thought to have low income levels. Given their scarce resources, they are expected to devote more resources towards necessities and therefore have relatively lower resources for saving. This is expected to lead to low saving rates. This is not observed in the data. The reason for this unexpectedly high saving rate may be precautionary behaviour. Having no security net to rely on, informally employed individuals save more than one would expect, in order to insure against uncertainties. This highlights the need for more detailed research on informally employed individuals with respect to their saving behaviour, with an emphasis on precautionary saving.

Table: 1

Mean and Standard Deviation of Saving Rates

\begin{tabular}{|l|c|c|c|c|c|c|c|c|}
\hline & \multicolumn{9}{|c|}{2015} & \multicolumn{5}{c|}{2016} \\
\hline & Contract (SSK) & Indep and artisans (BK) & Public (ES) & Informal & Contract (SSK) & Indep and artisans (BK) & Public (ES) & Informal \\
\hline Mean & 0.26 & 0.34 & 0.29 & 0.35 & 0.26 & 0.33 & 0.27 & 0.30 \\
\hline Std dev & 0.10 & 0.12 & 0.11 & 0.21 & 0.09 & 0.12 & 0.17 & 0.18 \\
\hline
\end{tabular}

Source: Authors' calculation based on 2015-2016 HBS.

The second point is the wide dispersion in the saving rates. To clarify, Table 1 has been prepared to present mean and standard deviation values of the saving rate for both years and all sub-samples. The table shows that the saving rate is most volatile for the informally 
employed group, and that the mean saving rate of this group is not necessarily less than the other groups.

Figure: 1

\section{Saving Rates (2015 and 2016)}

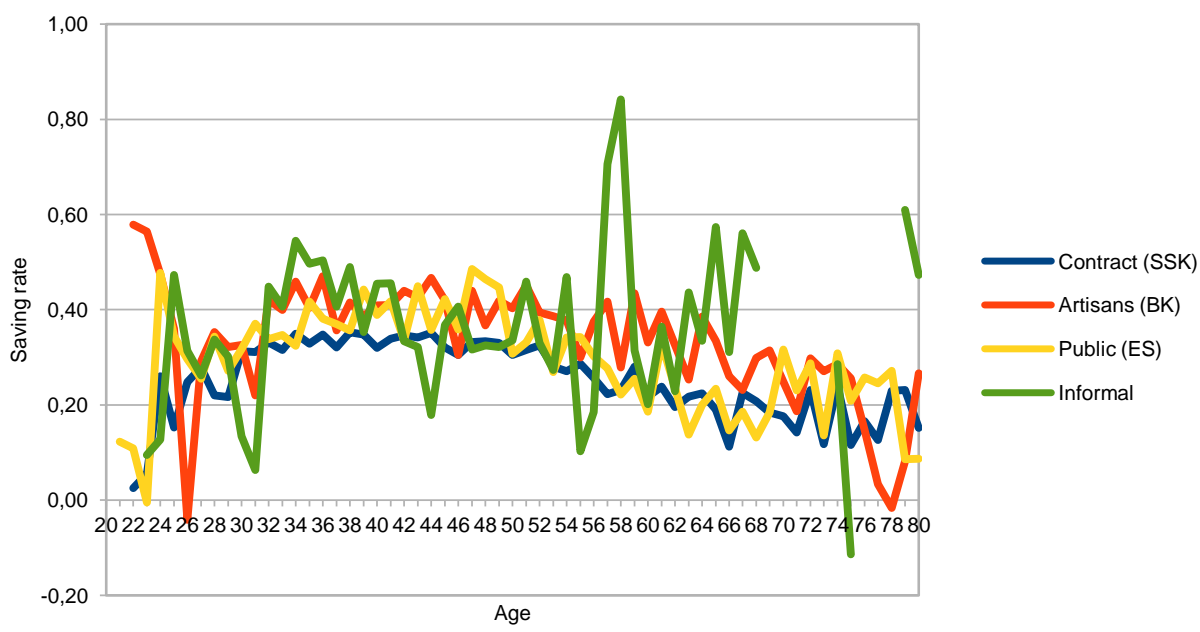

(a) Year 2015

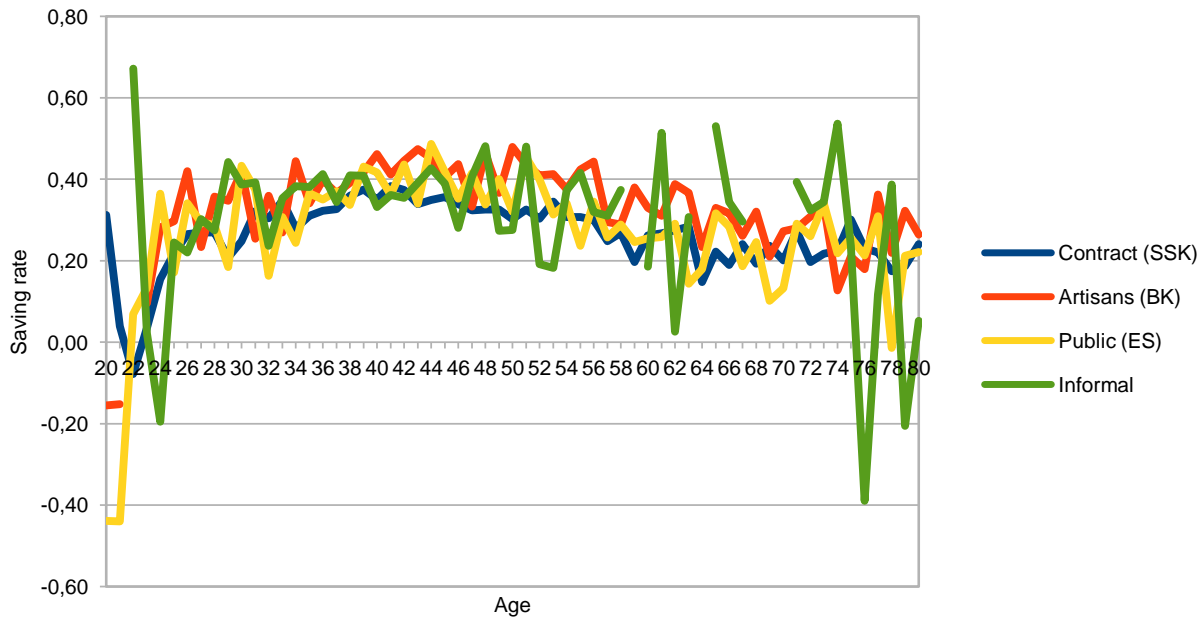

(b) Year 2016

Source: Authors' compilation from 2015 and 2016 HBS. Calculation details are in text. 


\section{Table: 2}

\section{Testing for Unobserved Heterogeneity}

\begin{tabular}{|l|c|}
\hline & Breusch-Pagan LM test \\
\hline Contract (SSK) & $0.64(0.2120)^{*}$ \\
\hline Independents and artisans (BK) & $0.00(1.00)^{*}$ \\
\hline Public servants (ES) & $0.38(0.2700)^{*}$ \\
\hline Informal & $0.13(0.3612)^{*}$ \\
\hline
\end{tabular}

Source: Authors'calculations. Probability values are reported, and compared to $1 \%$.

For the Breusch-Pagan test, * implies that $H_{0}$ can not be rejected.

As part of the panel data investigation, we first consider the existence of cross sectional heterogeneity through a Breusch-Pagan LM test (Breusch and Pagan, 1980). The results are presented in Table 2 . The null hypothesis of homogeneity across cross section units can not be rejected and a pooled OLS approach is favoured by the test. Coefficients from estimated models are presented in Table 3. The age polynomials implied by the estimated coefficients are visualised in Figure 2.

Table: 3

\section{Estimation Results on the Pseudo-Panel Sets}

\begin{tabular}{|c|c|c|c|c|}
\hline & Contract (SSK) Pooled OLS & Indep. and artisans (BK) Pooled OLS & Public (ES) Fixed effects & $\begin{array}{c}\text { Informal } \\
\text { Pooled OLS }\end{array}$ \\
\hline Age & 0.05874549 & 0.0654341 & 0.1339491 & 0.0339058 \\
\hline $\mathrm{Age}^{2}$ & -0.001087 & -0.001129 & -0.0025581 & -0.0004385 \\
\hline $\mathrm{Age}^{3}$ & $6.21 \mathrm{e}-06$ & $5.74 \mathrm{E}-06$ & $1.51 \mathrm{E}-05$ & $1.23 \mathrm{E}-06$ \\
\hline Period & 0.0042533 & -0.0080932 & -0.0204787 & -0.0421486 \\
\hline Constant & -0.6241311 & -0.7525913 & -1.807083 & -0.3369664 \\
\hline
\end{tabular}

Source: Authors' calculations.

\section{Figure: 2}

Age Effects

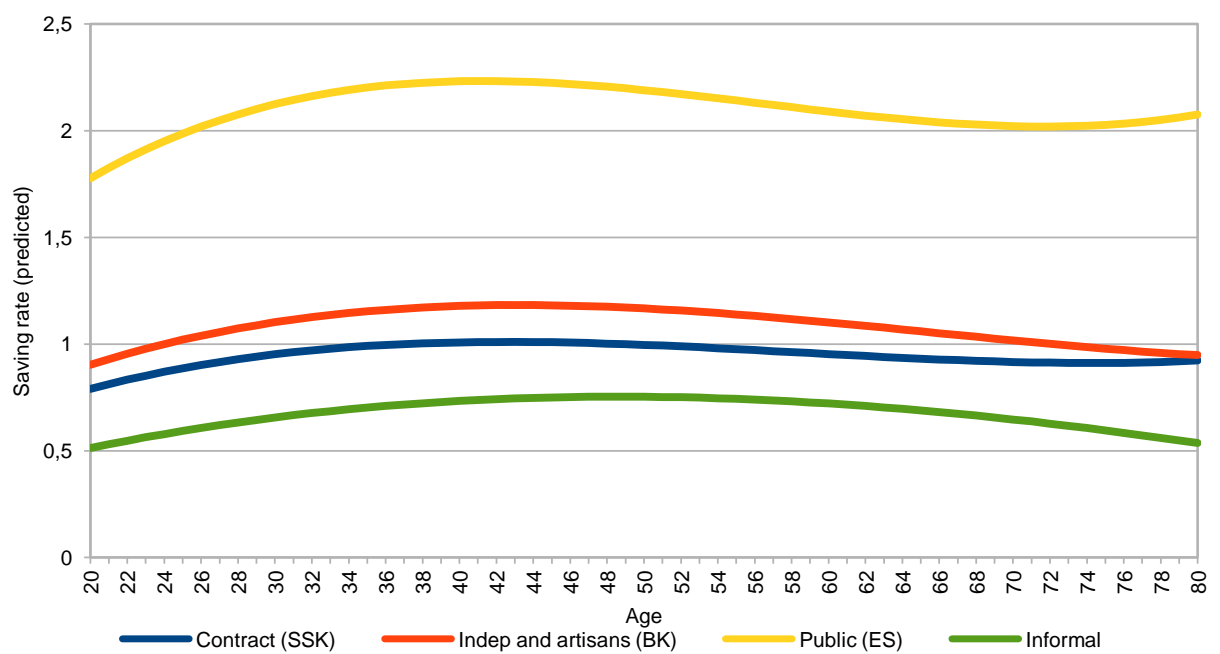

Source: Authors'calculations. 
It should be cautioned that Figure 2 represents the impact of being at a certain age on the saving rate. Thus this is not the level of saving at a certain age. Hence one can not deduce from Figure 2 that the saving rate of public workers is higher than other groups. What can be concluded is that age effects are much higher for public workers compared to other groups. Informally employed workers have the lowest impact.

We observe the existence of a hunchback profile regarding the impact of age on saving rates. The effect is most dominant for public workers. Possible explanation is the way public wages are increased through seniority. The progress of a public servant's wage income is based on seniority charts and public servants move along these charts automatically, with little regard to job performance. Hence spending time at a job, and therefore age, is an important factor on income. It can be argued that what we are observing here is a reflection of this income dynamic on saving behaviour.

Table: 4

Variable Definitions

\begin{tabular}{|l|l|l|}
\hline Name & Definition & Source \\
\hline Income (I) & Annual disposable income. & Obtained directly from the 2016 Household Budget Survey. Square calculated by the authors. \\
\hline Wealth (W) & Sum of rental income. & $\begin{array}{l}\text { Calculated as the sum of rental income from house, apartment, summer residence, field, vineyard, } \\
\text { greenhouse, land, shop and hotel; obtained from 2016 Household Budget Survey. }\end{array}$ \\
\hline $\begin{array}{l}\text { Financial } \\
\text { Literacy (FL) }\end{array}$ & $\begin{array}{l}\text { The different methods } \\
\text { household uses to save. }\end{array}$ & $\begin{array}{l}\text { Compiled by the authors based on a question in the 2016 Household Budget Survey. The question } \\
\text { asks how many different methods household uses to save. FL is a discrete variable ranging from 0 to } \\
\text { 4, with 4 representing the highest level of financial literacy. }\end{array}$ \\
\hline Education (E) & $\begin{array}{l}\text { Highest level of education } \\
\text { completed by the household } \\
\text { head. }\end{array}$ & $\begin{array}{l}\text { Compiled by the authors from the 2016 Household Budget Survey. It accounts for 12 different } \\
\text { education levels starting from illiterate (level 1) to completed doctorate education (level 12). Square } \\
\text { calculated by the authors. }\end{array}$ \\
\hline Age (A) & Age of the household head. & Obtained directly from the 2016 Household Budget Survey. \\
\hline
\end{tabular}

\subsection{Truncated Regression: Method}

Second stage of the empirical investigation is based on the econometric analysis of a cross section database. Such studies are frequently done for large datasets. Aksoy (2016: 11 and 24) presents studies on Turkey and various countries. A quick review of the literature reveals that the common set of variable in such studies are income, education level, household demographic structure and wealth indicators. The unit of analysis is not the individual but the household. This is a reflection of the fact that data is often gathered from family units.

The data used in this analysis are obtained by merging the individuals and households datasets of the 2016 Household Budget Survey of Turkey. Definitions of variables are provided in Table 4. As the income variable, the annual disposable income available in the dataset has been directly utilised. As an indicator of households wealth, aggregate rental income is used.

Financial literacy is represented by the number of different saving methods used by the household. The HBS questionnaire has four questions regarding whether different saving methods are used. A financial literacy variable based on these questions has been constructed. From the individuals dataset of the Survey, education and age information on the household head has been gathered. 
The estimation equation is stated as follows:

$s_{i}=\beta_{0}+\beta_{1} I_{i}+\beta_{2} I_{i}^{2}+\beta_{3} W_{i}+\beta_{4} \mathrm{FL}_{i}+\beta_{5} E_{i}+\beta_{5} E_{i}^{2}+\sum_{\mathrm{j}=\mathrm{SSK}, \mathrm{BK}, \mathrm{ES}, \mathrm{INF}} D_{\mathrm{i}, \mathrm{j}}\left[\delta_{1, \mathrm{j}} A_{i}+\delta_{2, \mathrm{j}} A_{i}^{2}+\delta_{3, \mathrm{j}} A_{i}^{3}\right]+\epsilon$

where:

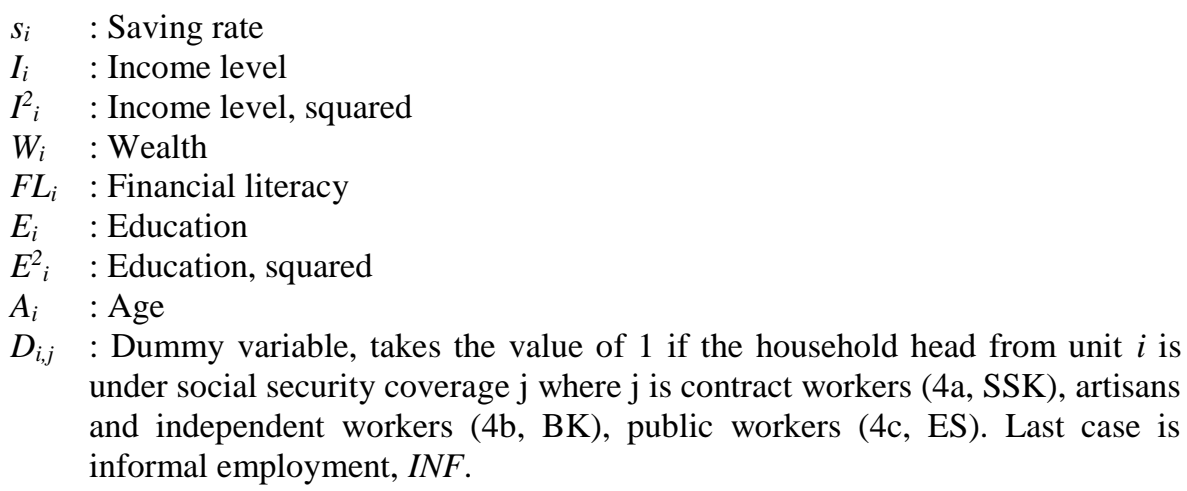

The age polynomial at the right side of Equation 2 represents the interaction between age, social security membership and saving rate. After controlling for income, wealth, financial literacy and education, it is possible to obtain age polynomials for individuals with different social security coverages.

Estimation of Equation 2 through an OLS approach is hardly recommended. For, as the data is compiled, extreme saving rate values below -0.5 and above 1 have been dropped from the data set. Thus the data set has been truncated, but the observations are nevertheless there. The estimated coefficients would be biased if OLS is adopted. An alternative approach is to assume that the dependent variable, saving rate, is restricted to the $[0,1]$ interval and choose the appropriate limited dependent variable estimation approach accordingly. However, restricting the saving rate to the $[0,1]$ interval eliminates the possibility that the saving rate may be negative. But theoretical perspectives on the life cycle behaviour of saving implies that the saving rate may be negative; hence completely eliminating the negative saving rates from the data would disconnect the study from an important theoretical aspect. However, eliminating extreme saving rates such as -10 is also important. Thus, the elimination of the saving rates below -0.5 and above 1 is decided, and the truncated regression approach is chosen as the appropriate estimation method.

\subsection{Truncated Regression: Analysis}

The adopted method has been applied to the data compiled from the 2016 Household Budget Survey dataset, using Equation 2 as the estimating equation. Estimation results are presented in Table 5. The estimation results come with coefficients of high statistical significance. Income, wealth and financial literacy are observed to be positively related to the saving rate. However, education is observed to have a negative relationship with the 
saving rate; i.e. a higher completed education level reduces the saving rate. Such a finding is not orginal and has been reported for a number of countries by various studies (Denizer \& Wolf, 1998: 12; Moriset \& Revoredo, 1995; Kulikov \& Paabut \& Staehr, 2007; Markos, 2015).

\section{Figure: 3}

\section{Age Polynomials of Saving Rate from Truncated Regression}

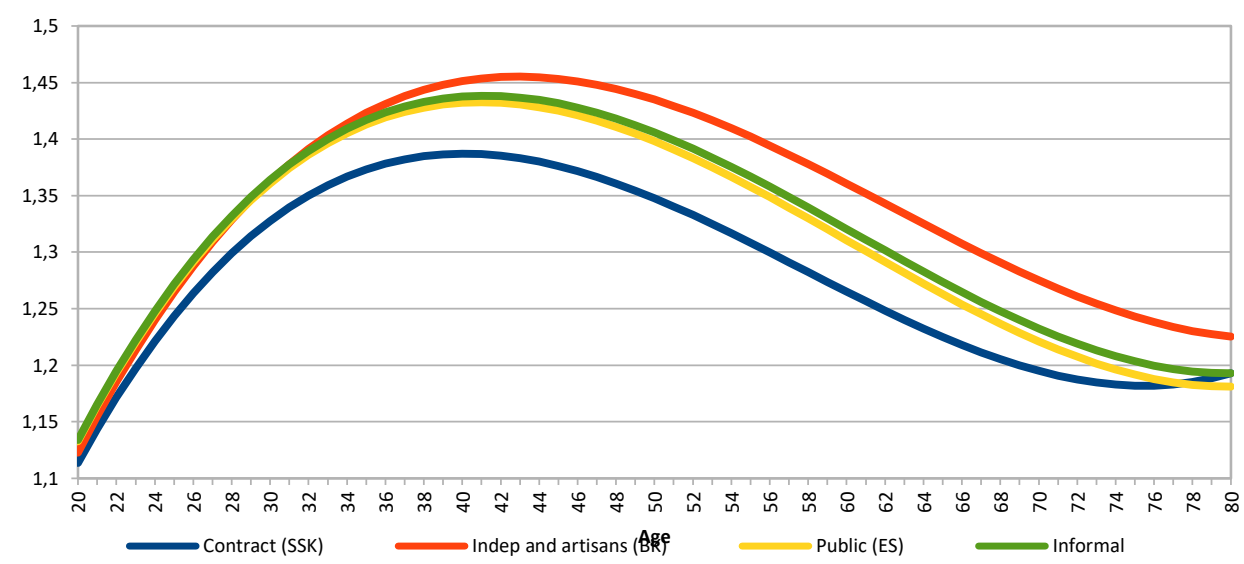

Source: Authors' calculations.

Table: 5

Estimation Results from Truncated Regression

\begin{tabular}{|c|c|}
\hline Constant Term & $-1.0699^{* * *}$ \\
\hline Income & $1.6962^{* * *}$ \\
\hline Income Squared & $-1.9655^{* * *}$ \\
\hline Wealth & $1.3095^{* *}$ \\
\hline Financial Literacy & $0.0637^{* * *}$ \\
\hline Education & 0.0002 \\
\hline Education Squared & $-0.0014^{* * *}$ \\
\hline \multicolumn{2}{|c|}{ Age Polynomial: Contract workers } \\
\hline Age & $0.0838^{* * *}$ \\
\hline $\mathrm{Age}^{2}$ & $-0.0016^{* * *}$ \\
\hline $\mathrm{Age}^{3}$ & $9.31 \mathrm{e}-06^{* * *}$ \\
\hline \multicolumn{2}{|c|}{ Age Polynomial: Independents and artisans } \\
\hline Age & $0.0819^{* * *}$ \\
\hline Age $^{2}$ & $-0.0015^{* * *}$ \\
\hline Age $^{3}$ & $7.82 \mathrm{e}-06^{* * *}$ \\
\hline \multicolumn{2}{|c|}{ Age Polynomial: Public workers } \\
\hline Age & $0.0848^{* * *}$ \\
\hline $\mathrm{Age}^{2}$ & $-0.0016^{* * *}$ \\
\hline Age $^{3}$ & $8.76 \mathrm{e}-06^{* * *}$ \\
\hline \multicolumn{2}{|c|}{ Age Polynomial: Informal } \\
\hline Age & $0.0842^{* * *}$ \\
\hline Age $^{2}$ & $-0.0016^{* * *}$ \\
\hline $\mathrm{Age}^{3}$ & $8.59 \mathrm{e}-06^{* * *}$ \\
\hline
\end{tabular}

Source: Authors' calculations. Probability values presented in parentheses.

** implies $5 \%$ significance.

*** implies $1 \%$ significance. 
The results for relating age and saving rate presented in Figure 3. The figure presents age polynomials based on the coefficients reported in Table 5. Two observations are imminent. Firstly, for all the groups the humpback profile is apparent. Secondly, the differences between the groups observed through the pseudo-panel analysis has disappeared. Contract workers now have the lowest profile, whereas independent workers and artisans have the highest. Thus the analysis strongly confirms the existence of the humpback profile but can not present a systematic difference between the groups investigated.

\section{Conclusion}

This paper investigates the existence of a humpback profile in savings for the case of Turkish data. Additionally, it is investigated whether the humpback profile differs by social security membership. Given the insufficiency of savings in Turkey, this paper contributes by providing more information on saving in Turkey. It also provides information for researchers planning to construct detailed economic models with intricate micro foundations for the Turkish case.

The analysis has been conducted on Household Budget Surveys by Turkish Statistics Institute. Two methods have been employed; a pseudo-panel analysis and a truncated regression estimation. The visual examination of the raw data of the constructed pseudopanel shows that there is a humpback profile, but there are no significant differences between actors with different social security membership. One finding from the raw data is the high volatility of the saving rate for informally employed individuals. A panel data analysis of the pseudo-panel dataset isolates age polynomials and confirms that humpback profile exists. One interesting finding at this stage is that the tail of the life profile of the saving rate does not turn down much at higher ages for public employees. This is believed to be a reflection of the automated seniority and wage increase system of public workers in Turkey.

Truncated regression analysis shows that income, wealth and financial literacy are positively related to the saving rate. An unexpected finding is that the education level is negatively related to saving. However, a review of applied literature shows that this is indeed the case for developing economies. A firm positive relationship between education and saving rate is an observation for developed countries.

The age polynomials from the truncated regression analysis once more confirm the humpback profile. However, the strict ranking of these profiles by social security membership, as observed through the pseudo-panel data, is lost. Now independent workers artisans group has the highest age polynomial while contract workers have the lowest polynomial.

We conclude that the humpback profile exists, but a systematic ranking across social security membership classifications has not been identified. Still, there is ample evidence for modellers to adopt a standard life cycle formulation of consumer behaviour for the Turkish case. The analysis provides a policy insight as well. Since saving behaviour tends to reach a peak in the middle parts of life, saving tools can be marketed to such individuals. 
However, the lower early age saving rate may be indicative of insufficient resources. Policies aimed at resource scarcity of younger people may have a side effect of improving saving. Further research into the existence of such a connection is definitely warranted.

\section{References}

Abdelhalek, T. \& F. Arestoff \& H. el M. de Freitas \& S. Mage (2010), “A Microeconometric Analysis of Household Savings Determinants in Morocco", African Review of Money, Finance and Banking, 7-27.

Aksoy, F. (2016), “Tasarrufun Belirleyicileri: Tüketici ve Ticari Kredilere İlişkin Bulgular”, Türkiye Cumhuriyet Merkez Bankası Dış İlişkiler Genel Müdürlüğü Uzmanlık Yeterlik Tezi, $<$ https://tinyurl.com/yar33d3o>, 03.07.2018.

Aktaş, A. \& D. Güner \& S. Gürsel \& G. Uysal (2012), "Structural Determinants of Household Savings in Turkey: 2003-2008”, BETAM Working Paper Series, 007, Bahçeşehir University, İstanbul, Turkey.

Attanasio, O.P. (1998), “Cohort Analysis of Saving Behavior by U.S. Households”, The Journal of Human Resources, 33(2), 575-609.

Auerbach, A.J. \& L.J. Kotlikoff (1987), Dynamic Fiscal Policy, Cambridge University Press.

Baidoo, S.T. \& E. Boateng \& M. Amponsah (2018), "Understanding the Determinants of Saving in Gahana: Does Financial Literacy Matter?”, Journal of International Development, 30(5), 886-903.

Bebczuk, R. \& L. Gasparini \& J. Amendolaggine \& N. Garbero (2015), “Understanding the Determinants of Household Saving: Micro Evidence for Latin America", Inter-American Development Bank Technical Note, IDB-TN-843, Inter-American Development Bank.

Breusch, T.S. \& A.R. Pagan (1980), “The Lagrange Multiplier Test and Its Applications to Model Specification in Econometrics", The Review of Economic Studies, 47(1), 239-253.

Brounen, D. \& K.G. Koedijk \& R.A.J. Pownall (2016), "Household Financial Planning and Savings Behavior", Journal of International Money and Finance, 69, 95-107.

Burney, N.A. \& A.H. Khan (1992), "Socio-economic Characteristics and Household Savings: An Analysis of the Households' Saving Behaviour in Pakistan”, The Pakistan Development Review, 31(1), 31-48.

Campbell, J.Y. (2006), "Household Finance”, The Journal of Finance, 61(4), 1553-1604.

Carroll, C.D. (1997), "Buffer-Stock Saving and the Life Cycle/Permanent Income Hypothesis", The Quarterly Journal of Economics, 112(1), 1-55.

Ceritoğlu, E. \& O. Eren (2014), "The Effects of Demographic and Social Changes on Household Savings in Turkey", Central Bank Review, 14(3), 15-33.

Ceritoğlu, E. (2013), “The Impact of Labour Income Risk on Household Saving Decisions in Turkey", Review of Economics of the Household, 11, 109-129.

Cilasun, S.M. (2009), "Income and Consumption and Saving Behavior of Turkish Households", Unpublished Dissertation, Middle East Technical University, Institute of Social Sciences, Ankara, Turkey.

Deaton, A. (1985), "Panel Data from Time Series of Cross Sections", Journal of Econometrics, 30(12), 109-126. 
Değer, Ç. (2011), “An Overlapping Generations Analysis of Social Security Reform in Turkey”, Unpublished Dissertation, Middle East Technical University, Institute of Social Sciences, Ankara, Turkey.

Denizer, C. \& H.C. Wolf (1998), "Household Savings in Transition Economies", NBER Working Paper, 6457, National Bureau of Economic Research, Cambridge, Mass.

Diamond, P. (1965), "National Debt in a Neoclassical Growth Model", American Economic Review, 55 (5), 1126-1150.

Duesenberry, J.S. (1949), Income, Saving and the Theory of Consumer Behaviour, Cambridge, MA: Harvard University Press.

Düzgün, R. (2009), “Türkiye'de Özel Tasarrufun Belirleyicileri”, Erciyes Üniversitesi İktisadi ve İdari Bilimler Fakültesi Dergisi, 32, 173-189.

Fisher, I. (1930), The Theory of Interest, New York: McMillan.

Friedman, M. (1957), A Theory of the Consumption Function, Princeton University Press.

Gibson, J.K. \& G.M. Scobie (2001), "Household Saving Behavior in New Zealand: A Cohort Analysis", Treasury Working Paper Series, 01/08, New Zealand Treasury, Wellington, New Zealand.

Harris, M.N. \& J. Loundes \& E. Webster (2002), "Determinants of Household Saving in Australia", The Economic Record, 78(241), 207-223.

Heckman, J.J. (1979), “Sample Selection Bias as a Specification Error”, Econometrica, 47(1), 153161.

Jappelli, T. \& M. Padula (2013), "Investment in Financial Literacy and Saving Decisions", Journal of Banking \& Finance, 37(8), 2779-2792.

Jappelli, T. (1999), "The Age Wealth Profile and the Life Cycle Hypothesis: A Cohort Analysis with a Time Series of Cross Section of Italian Households", The Review of Income and Wealth, 45(1), 57-75.

Keynes, J.M. (1936), The General Theory of Employment, Interest and Money, MacMillan, London.

Kulikov, D. \& A. Paabut \& K. Staehr (2008), "A Microeconometric Analysis of Household Saving in Estonia: Income, Wealth and Financial Exposure", Bank of Estonia Working Paper Series, 8/2007, Bank of Estonia, Tallinn, Estonia.

Kuznets, S. (1942), Uses of National Income in Peace and War, National Bureau of Economic Research, New York.

Long, J.S. (1997), Regression Models for Categorical and Limited Dependent Variables, Sage Publications, London.

Lusardi, A. \& O.S. Mitchell (2014), "The Economic Importance of Financial Literacy: Theory and Evidence", Journal of Economic Literature, 52(1), 5-44.

Markos, W. (2015), "Determinants and Behaviour of Rural Household Saving: A Case of Dale Woreda, Sidama Zone", International Journal of Multidisciplinary Advanced Research Trends, 2(3), 1-9.

Matur, E.P. \& A. Sabuncu \& S. Bahçeci (2012), "Determinants of Private Savings and Interaction Between Public and Private Savings in Turkey", Topics in Middle Eastern and North African Economies, 14, 102-125.

Modigliani, F. (1966), "The Life Cycle Hypothesis of Saving, the Demand for Wealth and the Supply of Capital", Social Research, 33(2), 160-217. 
Morisset, J. \& C. Revoredo (1995), "Savings and Education A Life-Cycle Model Applied to a Panel of 74 Countries", World Bank Policy Research Working Paper, 1504, World Bank, Washington D.C.

Murendo, C. \& K. Mutsonziwa (2016), "Financial Literacy and Savings Decisions by Adult Financial Consumers in Zimbabwe", International Journal of Consumer Studies, 41(1), 95-103.

Nagatani, K. (1972), “Life Cycle Saving: Theory and Fact”, The American Economic Review. 62(3), 344-353.

Obayelu, O.A. (2013), "Determinants of Savings Rate in Rural Nigeria: A Micro Study of Kwara State", Journal for the Advancement of Developing Economies, 2(1), 2-18.

Özcan, K.M. \& A. Günay \& S. Ertaç (2003), "Determinants of Private Savings Behaviour in Turkey", Applied Economics, 35(12), 1405-1416.

Rehman, H. ur \& M. Z. Faridi \& F. Bashir (2010), "Households Saving Behaviour in Pakistan: A Case of Multan District", Pakistan Journal of Social Sciences, 30(1), 17-29.

Rijckeghem, C.V. \& M. Üçer (2009), "The Evolution and Determinants of the Turkish Private Saving Rate: What Lessons for Policy?" ERF Research Report Series, 09-01, Economic Research Forum, Giza, Egypt.

Snyder, D.W. (1974), "Econometric Studies of Household Saving Behaviour in Developing Countries: A Survey", The Journal of Development Studies, 10(2), 139-153.

Tatliyer, M. (2017), "Determinants of Private Saving Level: Evidence from Turkey”, Sosyoekonomi, 25(32), 149-167.

Tobin, J. (1958), "Estimation of Relationships for Limited Dependent Variables”, Econometrica, 26(1), 24-36.

Toth, M. \& D. Lancaric \& R. Savov (2015), "Impact of Education on the Financial Literacy: The Case of Slovakia", Trendy v Podnikani: Business Trends, 5(2), 27-35. 
Değer, Ç. \& E. Erer (2020), "Social Security Membership and

Saving: The Turkish Case", Sosyoekonomi, Vol. 28(43), 257-275.

\section{Appendixes}

Table: 1

Descriptive Statistics by Age (2015)

\begin{tabular}{|c|c|c|c|c|c|c|c|c|c|c|c|c|}
\hline & \multicolumn{3}{|c|}{ BK (artisans, independent workers) } & \multicolumn{3}{|c|}{ ES (public workers) } & \multicolumn{3}{|c|}{ SSK (contract workers) } & \multicolumn{3}{|c|}{ Informal } \\
\hline Age & \# of obs. & Mean & Std dev & \# of obs. & Mean & Std dev & \# of obs. & Mean & Std dev & \# of obs. & Mean & Std dev \\
\hline 21 & 0 & & & 3 & 0.123 & 0.284 & 0 & & & 2 & -0.109 & 0.396 \\
\hline 22 & 1 & 0.579 & & 2 & 0.109 & 0.166 & 9 & 0.025 & 0.397 & 0 & & \\
\hline 23 & 1 & 0.564 & & 5 & -0.005 & 0.324 & 14 & 0.055 & 0.299 & 4 & 0.095 & 0.390 \\
\hline 24 & 2 & 0.475 & 0.570 & 5 & 0.478 & 0.135 & 12 & 0.261 & 0.370 & 1 & 0.127 & \\
\hline 25 & 6 & 0.360 & 0.492 & 7 & 0.344 & 0.162 & 34 & 0.153 & 0.275 & 5 & 0.473 & 0.249 \\
\hline 26 & 7 & -0.041 & 0.253 & 13 & 0.297 & 0.287 & 45 & 0.248 & 0.278 & 3 & 0.314 & 0.231 \\
\hline 27 & 5 & 0.292 & 0.218 & 16 & 0.255 & 0.350 & 61 & 0.278 & 0.266 & 7 & 0.262 & 0.420 \\
\hline 28 & 9 & 0.353 & 0.329 & 17 & 0.344 & 0.267 & 59 & 0.220 & 0.334 & 13 & 0.337 & 0.355 \\
\hline 29 & 11 & 0.321 & 0.305 & 20 & 0.272 & 0.276 & 83 & 0.216 & 0.280 & 5 & 0.301 & 0.360 \\
\hline 30 & 15 & 0.326 & 0.163 & 22 & 0.317 & 0.256 & 95 & 0.313 & 0.249 & 11 & 0.134 & 0.402 \\
\hline 31 & 20 & 0.220 & 0.362 & 12 & 0.370 & 0.273 & 84 & 0.311 & 0.286 & 5 & 0.063 & 0.439 \\
\hline 32 & 25 & 0.421 & 0.341 & 20 & 0.338 & 0.296 & 119 & 0.331 & 0.278 & 9 & 0.448 & 0.319 \\
\hline 33 & 22 & 0.399 & 0.268 & 24 & 0.347 & 0.200 & 107 & 0.316 & 0.266 & 12 & 0.407 & 0.309 \\
\hline 34 & 32 & 0.459 & 0.252 & 31 & 0.324 & 0.367 & 152 & 0.350 & 0.265 & 12 & 0.545 & 0.192 \\
\hline 35 & 47 & 0.404 & 0.278 & 30 & 0.417 & 0.219 & 164 & 0.329 & 0.289 & 14 & 0.496 & 0.216 \\
\hline 36 & 28 & 0.471 & 0.285 & 21 & 0.381 & 0.312 & 121 & 0.348 & 0.249 & 7 & 0.504 & 0.307 \\
\hline 37 & 37 & 0.357 & 0.286 & 33 & 0.369 & 0.260 & 143 & 0.321 & 0.277 & 12 & 0.406 & 0.319 \\
\hline 38 & 32 & 0.416 & 0.326 & 21 & 0.357 & 0.331 & 142 & 0.353 & 0.269 & 13 & 0.490 & 0.220 \\
\hline 39 & 39 & 0.386 & 0.308 & 27 & 0.443 & 0.200 & 102 & 0.348 & 0.261 & 14 & 0.353 & 0.344 \\
\hline 40 & 41 & 0.409 & 0.300 & 33 & 0.389 & 0.282 & 173 & 0.319 & 0.290 & 21 & 0.455 & 0.271 \\
\hline 41 & 37 & 0.410 & 0.308 & 34 & 0.418 & 0.231 & 142 & 0.339 & 0.276 & 13 & 0.455 & 0.349 \\
\hline 42 & 51 & 0.440 & 0.255 & 33 & 0.336 & 0.334 & 145 & 0.346 & 0.250 & 22 & 0.333 & 0.327 \\
\hline 43 & 48 & 0.426 & 0.332 & 35 & 0.449 & 0.265 & 131 & 0.342 & 0.287 & 10 & 0.321 & 0.247 \\
\hline 44 & 42 & 0.467 & 0.256 & 36 & 0.358 & 0.297 & 122 & 0.351 & 0.274 & 18 & 0.179 & 0.325 \\
\hline 45 & 46 & 0.420 & 0.281 & 35 & 0.422 & 0.229 & 143 & 0.321 & 0.279 & 17 & 0.368 & 0.320 \\
\hline 46 & 32 & 0.305 & 0.360 & 34 & 0.358 & 0.258 & 118 & 0.305 & 0.297 & 16 & 0.406 & 0.289 \\
\hline 47 & 42 & 0.440 & 0.330 & 29 & 0.485 & 0.199 & 109 & 0.332 & 0.269 & 15 & 0.317 & 0.302 \\
\hline 48 & 45 & 0.367 & 0.302 & 28 & 0.465 & 0.298 & 126 & 0.334 & 0.305 & 13 & 0.325 & 0.457 \\
\hline 49 & 39 & 0.418 & 0.336 & 28 & 0.447 & 0.260 & 112 & 0.331 & 0.269 & 15 & 0.321 & 0.383 \\
\hline 50 & 59 & 0.403 & 0.336 & 32 & 0.307 & 0.290 & 141 & 0.305 & 0.307 & 16 & 0.336 & 0.348 \\
\hline 51 & 41 & 0.451 & 0.328 & 42 & 0.331 & 0.312 & 114 & 0.315 & 0.297 & 4 & 0.459 & 0.336 \\
\hline 52 & 52 & 0.394 & 0.328 & 46 & 0.379 & 0.255 & 144 & 0.325 & 0.301 & 12 & 0.330 & 0.308 \\
\hline 53 & 52 & 0.387 & 0.319 & 35 & 0.269 & 0.312 & 101 & 0.281 & 0.326 & 4 & 0.273 & 0.420 \\
\hline 54 & 40 & 0.378 & 0.349 & 28 & 0.341 & 0.307 & 125 & 0.271 & 0.313 & 12 & 0.469 & 0.269 \\
\hline 55 & 61 & 0.300 & 0.311 & 45 & 0.343 & 0.293 & 123 & 0.287 & 0.324 & 7 & 0.103 & 0.410 \\
\hline 56 & 47 & 0.375 & 0.317 & 32 & 0.302 & 0.335 & 82 & 0.257 & 0.280 & 4 & 0.185 & 0.249 \\
\hline 57 & 36 & 0.417 & 0.334 & 31 & 0.277 & 0.315 & 91 & 0.223 & 0.324 & 1 & 0.706 & \\
\hline 58 & 48 & 0.279 & 0.319 & 36 & 0.222 & 0.378 & 99 & 0.231 & 0.345 & 1 & 0.842 & \\
\hline 59 & 52 & 0.434 & 0.328 & 45 & 0.255 & 0.333 & 80 & 0.280 & 0.308 & 3 & 0.315 & 0.184 \\
\hline 60 & 72 & 0.331 & 0.364 & 38 & 0.186 & 0.317 & 124 & 0.218 & 0.328 & 3 & 0.201 & 0.280 \\
\hline 61 & 39 & 0.396 & 0.299 & 50 & 0.329 & 0.271 & 73 & 0.238 & 0.313 & 1 & 0.365 & \\
\hline 62 & 43 & 0.326 & 0.295 & 22 & 0.236 & 0.261 & 72 & 0.196 & 0.311 & 3 & 0.229 & 0.319 \\
\hline 63 & 45 & 0.253 & 0.267 & 31 & 0.138 & 0.302 & 70 & 0.217 & 0.286 & 4 & 0.436 & 0.193 \\
\hline 64 & 34 & 0.386 & 0.345 & 23 & 0.200 & 0.234 & 56 & 0.224 & 0.272 & 2 & 0.335 & 0.253 \\
\hline 65 & 63 & 0.335 & 0.317 & 26 & 0.234 & 0.282 & 110 & 0.190 & 0.352 & 2 & 0.574 & 0.218 \\
\hline 66 & 30 & 0.260 & 0.260 & 23 & 0.146 & 0.303 & 58 & 0.112 & 0.307 & 2 & 0.311 & 0.057 \\
\hline 67 & 47 & 0.231 & 0.376 & 22 & 0.186 & 0.298 & 55 & 0.225 & 0.283 & 1 & 0.561 & \\
\hline 68 & 40 & 0.299 & 0.366 & 16 & 0.131 & 0.342 & 45 & 0.208 & 0.299 & 4 & 0.488 & 0.278 \\
\hline 69 & 28 & 0.315 & 0.358 & 14 & 0.184 & 0.313 & 39 & 0.184 & 0.323 & 0 & & \\
\hline 70 & 49 & 0.248 & 0.328 & 15 & 0.316 & 0.290 & 39 & 0.176 & 0.351 & 2 & 0.688 & 0.164 \\
\hline 71 & 28 & 0.186 & 0.308 & 11 & 0.231 & 0.257 & 36 & 0.142 & 0.317 & 0 & & \\
\hline 72 & 26 & 0.297 & 0.320 & 11 & 0.287 & 0.252 & 43 & 0.232 & 0.273 & 1 & 0.564 & \\
\hline 73 & 22 & 0.271 & 0.268 & 11 & 0.136 & 0.260 & 31 & 0.117 & 0.278 & 0 & & \\
\hline 74 & 36 & 0.286 & 0.308 & 12 & 0.308 & 0.321 & 23 & 0.240 & 0.240 & 1 & 0.286 & \\
\hline 75 & 35 & 0.256 & 0.342 & 13 & 0.208 & 0.325 & 35 & 0.116 & 0.339 & 2 & -0.114 & 0.515 \\
\hline 76 & 12 & 0.148 & 0.377 & 17 & 0.257 & 0.313 & 24 & 0.165 & 0.331 & 0 & & \\
\hline 77 & 26 & 0.033 & 0.336 & 6 & 0.245 & 0.230 & 18 & 0.127 & 0.369 & 1 & -0.341 & \\
\hline 78 & 19 & -0.016 & 0.271 & 9 & 0.271 & 0.231 & 23 & 0.229 & 0.334 & 0 & & \\
\hline 79 & 17 & 0.082 & 0.351 & 4 & 0.086 & 0.299 & 20 & 0.232 & 0.317 & 1 & 0.609 & \\
\hline 80 & 21 & 0.266 & 0.335 & 4 & 0.087 & 0.342 & 15 & 0.152 & 0.238 & 0 & & \\
\hline
\end{tabular}

Source: Authors'calculations. 
Değer, Ç. \& E. Erer (2020), "Social Security Membership and

Saving: The Turkish Case", Sosyoekonomi, Vol. 28(43), 257-275.

Table: 2

Descriptive Statistics by Age (2016)

\begin{tabular}{|c|c|c|c|c|c|c|c|c|c|c|c|c|}
\hline & \multicolumn{3}{|c|}{ BK (artisans, independent workers) } & \multicolumn{3}{|c|}{ ES (public workers) } & \multicolumn{3}{|c|}{ SSK (contract workers) } & \multicolumn{3}{|c|}{ Informal } \\
\hline Age & \# of obs. & Mean & Std dev & \# of obs. & Mean & Std dev & \# of obs. & Mean & Std dev & \# of obs. & Mean & Std dev \\
\hline 21 & 1 & -0.152 & & 1 & -0.440 & & 5 & 0.039 & 0.403 & 0 & & \\
\hline 22 & 0 & & & 7 & 0.068 & 0.375 & 5 & -0.078 & 0.287 & 1 & 0.672 & \\
\hline 23 & 3 & 0.095 & 0.170 & 5 & 0.133 & 0.475 & 20 & 0.035 & 0.345 & 7 & 0.022 & 0.329 \\
\hline 24 & 5 & 0.282 & 0.275 & 6 & 0.364 & 0.197 & 17 & 0.154 & 0.351 & 4 & -0.196 & 0.173 \\
\hline 25 & 1 & 0.297 & & 17 & 0.171 & 0.370 & 24 & 0.218 & 0.312 & 6 & 0.245 & 0.423 \\
\hline 26 & 5 & 0.420 & 0.377 & 16 & 0.341 & 0.209 & 49 & 0.266 & 0.305 & 5 & 0.220 & 0.408 \\
\hline 27 & 7 & 0.233 & 0.307 & 21 & 0.294 & 0.291 & 57 & 0.269 & 0.258 & 10 & 0.302 & 0.253 \\
\hline 28 & 11 & 0.357 & 0.247 & 22 & 0.288 & 0.353 & 77 & 0.270 & 0.313 & 9 & 0.275 & 0.426 \\
\hline 29 & 14 & 0.347 & 0.288 & 23 & 0.185 & 0.318 & 83 & 0.208 & 0.328 & 5 & 0.442 & 0.248 \\
\hline 30 & 12 & 0.419 & 0.161 & 19 & 0.433 & 0.319 & 87 & 0.248 & 0.279 & 14 & 0.387 & 0.339 \\
\hline 31 & 22 & 0.254 & 0.304 & 28 & 0.375 & 0.304 & 93 & 0.321 & 0.288 & 15 & 0.392 & 0.195 \\
\hline 32 & 15 & 0.360 & 0.408 & 23 & 0.163 & 0.280 & 86 & 0.304 & 0.262 & 5 & 0.236 & 0.484 \\
\hline 33 & 19 & 0.269 & 0.309 & 52 & 0.307 & 0.293 & 126 & 0.347 & 0.266 & 18 & 0.353 & 0.280 \\
\hline 34 & 29 & 0.444 & 0.285 & 27 & 0.244 & 0.362 & 126 & 0.279 & 0.308 & 13 & 0.383 & 0.270 \\
\hline 35 & 52 & 0.341 & 0.322 & 41 & 0.366 & 0.277 & 139 & 0.311 & 0.268 & 14 & 0.381 & 0.318 \\
\hline 36 & 34 & 0.398 & 0.292 & 29 & 0.350 & 0.283 & 146 & 0.322 & 0.302 & 19 & 0.412 & 0.302 \\
\hline 37 & 29 & 0.365 & 0.326 & 28 & 0.371 & 0.297 & 144 & 0.327 & 0.280 & 19 & 0.344 & 0.284 \\
\hline 38 & 35 & 0.391 & 0.341 & 35 & 0.337 & 0.322 & 169 & 0.359 & 0.284 & 20 & 0.410 & 0.358 \\
\hline 39 & 35 & 0.417 & 0.309 & 38 & 0.431 & 0.277 & 142 & 0.375 & 0.247 & 13 & 0.409 & 0.287 \\
\hline 40 & 54 & 0.462 & 0.266 & 49 & 0.417 & 0.275 & 149 & 0.350 & 0.282 & 13 & 0.332 & 0.267 \\
\hline 41 & 34 & 0.411 & 0.325 & 40 & 0.361 & 0.360 & 116 & 0.383 & 0.248 & 18 & 0.362 & 0.342 \\
\hline 42 & 45 & 0.445 & 0.314 & 40 & 0.436 & 0.277 & 142 & 0.374 & 0.264 & 15 & 0.355 & 0.276 \\
\hline 43 & 47 & 0.474 & 0.221 & 46 & 0.340 & 0.310 & 141 & 0.339 & 0.277 & 18 & 0.391 & 0.265 \\
\hline 44 & 50 & 0.452 & 0.331 & 41 & 0.487 & 0.253 & 131 & 0.350 & 0.283 & 19 & 0.427 & 0.278 \\
\hline 45 & 50 & 0.406 & 0.316 & 47 & 0.418 & 0.268 & 161 & 0.356 & 0.313 & 26 & 0.389 & 0.342 \\
\hline 46 & 50 & 0.438 & 0.312 & 37 & 0.353 & 0.303 & 137 & 0.339 & 0.281 & 15 & 0.281 & 0.432 \\
\hline 47 & 37 & 0.333 & 0.368 & 24 & 0.414 & 0.222 & 116 & 0.324 & 0.291 & 20 & 0.406 & 0.334 \\
\hline 48 & 39 & 0.464 & 0.275 & 33 & 0.338 & 0.292 & 115 & 0.325 & 0.307 & 15 & 0.481 & 0.294 \\
\hline 49 & 31 & 0.367 & 0.313 & 32 & 0.400 & 0.288 & 107 & 0.326 & 0.291 & 13 & 0.273 & 0.440 \\
\hline 50 & 50 & 0.479 & 0.285 & 44 & 0.321 & 0.298 & 173 & 0.302 & 0.301 & 14 & 0.276 & 0.317 \\
\hline 51 & 38 & 0.435 & 0.324 & 36 & 0.454 & 0.218 & 133 & 0.325 & 0.276 & 12 & 0.480 & 0.210 \\
\hline 52 & 43 & 0.410 & 0.336 & 50 & 0.400 & 0.305 & 120 & 0.303 & 0.345 & 8 & 0.192 & 0.350 \\
\hline 53 & 37 & 0.413 & 0.264 & 38 & 0.313 & 0.333 & 127 & 0.345 & 0.287 & 10 & 0.182 & 0.404 \\
\hline 54 & 35 & 0.376 & 0.276 & 29 & 0.341 & 0.311 & 110 & 0.307 & 0.319 & 3 & 0.373 & 0.359 \\
\hline 55 & 38 & 0.424 & 0.297 & 39 & 0.236 & 0.331 & 120 & 0.307 & 0.315 & 10 & 0.415 & 0.374 \\
\hline 56 & 49 & 0.443 & 0.349 & 35 & 0.345 & 0.287 & 131 & 0.300 & 0.307 & 7 & 0.320 & 0.226 \\
\hline 57 & 34 & 0.295 & 0.314 & 22 & 0.257 & 0.356 & 81 & 0.247 & 0.332 & 4 & 0.310 & 0.301 \\
\hline 58 & 40 & 0.288 & 0.323 & 38 & 0.289 & 0.321 & 83 & 0.269 & 0.327 & 5 & 0.374 & 0.353 \\
\hline 59 & 45 & 0.380 & 0.270 & 35 & 0.245 & 0.315 & 82 & 0.197 & 0.342 & 0 & & \\
\hline 60 & 74 & 0.330 & 0.315 & 48 & 0.255 & 0.322 & 119 & 0.263 & 0.297 & 3 & 0.185 & 0.378 \\
\hline 61 & 50 & 0.310 & 0.309 & 48 & 0.259 & 0.270 & 86 & 0.267 & 0.265 & 5 & 0.514 & 0.430 \\
\hline 62 & 58 & 0.388 & 0.308 & 35 & 0.291 & 0.254 & 85 & 0.274 & 0.315 & 1 & 0.026 & \\
\hline 63 & 43 & 0.366 & 0.322 & 36 & 0.143 & 0.316 & 78 & 0.284 & 0.304 & 2 & 0.307 & 0.815 \\
\hline 64 & 36 & 0.233 & 0.342 & 18 & 0.179 & 0.331 & 80 & 0.148 & 0.296 & 0 & & \\
\hline 65 & 68 & 0.330 & 0.356 & 38 & 0.317 & 0.280 & 104 & 0.223 & 0.343 & 4 & 0.530 & 0.292 \\
\hline 66 & 42 & 0.317 & 0.264 & 20 & 0.284 & 0.259 & 77 & 0.189 & 0.319 & 1 & 0.344 & \\
\hline 67 & 53 & 0.261 & 0.312 & 25 & 0.187 & 0.313 & 66 & 0.241 & 0.279 & 1 & 0.296 & \\
\hline 68 & 38 & 0.320 & 0.284 & 14 & 0.246 & 0.260 & 54 & 0.193 & 0.297 & 0 & & \\
\hline 69 & 26 & 0.210 & 0.312 & 24 & 0.101 & 0.320 & 43 & 0.237 & 0.282 & 2 & 0.200 & 0.355 \\
\hline 70 & 51 & 0.273 & 0.347 & 25 & 0.133 & 0.263 & 42 & 0.201 & 0.296 & 0 & & \\
\hline 71 & 27 & 0.279 & 0.301 & 12 & 0.291 & 0.329 & 42 & 0.274 & 0.271 & 1 & 0.393 & \\
\hline 72 & 29 & 0.309 & 0.369 & 12 & 0.260 & 0.349 & 29 & 0.197 & 0.277 & 3 & 0.323 & 0.170 \\
\hline 73 & 24 & 0.337 & 0.326 & 15 & 0.341 & 0.309 & 38 & 0.217 & 0.296 & 2 & 0.344 & 0.561 \\
\hline 74 & 22 & 0.127 & 0.394 & 10 & 0.218 & 0.308 & 34 & 0.225 & 0.295 & 1 & 0.536 & \\
\hline 75 & 35 & 0.210 & 0.298 & 19 & 0.256 & 0.256 & 31 & 0.301 & 0.328 & 1 & 0.237 & \\
\hline 76 & 30 & 0.179 & 0.341 & 11 & 0.213 & 0.384 & 35 & 0.230 & 0.306 & 1 & -0.390 & \\
\hline 77 & 24 & 0.363 & 0.273 & 8 & 0.309 & 0.237 & 21 & 0.220 & 0.326 & 2 & 0.117 & 0.513 \\
\hline 78 & 25 & 0.219 & 0.292 & 12 & -0.014 & 0.300 & 23 & 0.174 & 0.302 & 2 & 0.387 & 0.307 \\
\hline 79 & 11 & 0.323 & 0.284 & 5 & 0.212 & 0.306 & 22 & 0.186 & 0.249 & 1 & -0.206 & \\
\hline 80 & 20 & 0.264 & 0.265 & 8 & 0.221 & 0.254 & 25 & 0.241 & 0.279 & 3 & 0.052 & 0.206 \\
\hline
\end{tabular}

Source: Authors' calculations. 
Değer, Ç. \& E. Erer (2020), "Social Security Membership and Saving: The Turkish Case", Sosyoekonomi, Vol. 28(43), 257-275. 